\title{
Effect of T6 on Mechanical Properties of TiB and Sr Modified ADC12/SiC Composite Produced by Stir Casting
}

\author{
Pritamara Wahyuningtyas ${ }^{1}$, Anne Zulfia Syahrial ${ }^{1,}{ }^{*}$, Wahyuaji Narottama Putra ${ }^{1}$, and \\ Budi Wahyu Utomo ${ }^{2}$ \\ ${ }^{1}$ Departement of Metallurgy and Materials Engineering, University of Indonesia, Jl. Margonda Raya, \\ Depok, West Jaca, 16424, Indonesia \\ ${ }^{2}$ Astra Honda Motor, Cikarang Barat, 17530, Indonesia
}

\begin{abstract}
A study of $\mathrm{ADC} 12$ (Al-Si aluminium alloy) composite is conducted to obtain a more sustainable material with enhanced properties for automotive industry purpose, such as train's brake shoe and bearing application. For those kind of utilization, material with durability, good elastic modulus, thermal stability, wear resistance, and high strength properties is needed due to its exposure to high temperature and heavy continuous application. ADC 12 acts as the matrix, reinforced with $3 \mathrm{vf} \%$ micro-SiC with $5 \mathrm{wt} \% \mathrm{Mg}$ wetting agent was fabricated by the stir casting method. The addition of $0.18 \mathrm{wt} \% \mathrm{Sr}$ and $0.15 \mathrm{wt} \% \mathrm{TiB}$ were expected to finer the grain morphology of the silicone eutectic phase and to acts as the grain refiner, respectively. Furthermore, T6 heat treatment was applied with aging temperature $150{ }^{\circ} \mathrm{C}, 170{ }^{\circ} \mathrm{C}, 190{ }^{\circ} \mathrm{C}, 210{ }^{\circ} \mathrm{C}$, and $230{ }^{\circ} \mathrm{C}$, following the prior $1 \mathrm{~h} 490^{\circ} \mathrm{C}$ solution treatment. The results obtained in this work showed enhancement in tensile strength with the value of $213 \mathrm{MPa}$, hardness value $75 \mathrm{HRB}$, and wear resistance. These values increase up to $115 \mathrm{MPa}$ for the UTS and $38 \mathrm{HRB}$ for the hardness value, as the impact of the refined grains from both modifiers and heat treatment.
\end{abstract}

Key words: Aluminum composite, artificial aging, micro-SiC, $\mathrm{Sr}$ modifier, TiB grain refiner.

\section{Introduction}

Metal matrix composite is considered as one of the most reliable material, especially for automotive industry due to metal matrix's basic properties which were modified by the reinforce [1]. Among all materials, aluminium is one of the most widely used matrix for composite due to its low density, ductility, and thermal conductivity [2]. However, the reinforce for aluminium matrix composite should be able to complement wear resistivity and other certain properties qualifications [3]. Reinforce is not the only contributing factor in enhancing composite. The addition of wetting agent such as magnesium and silicone is also important to strengthen the interface between and matrix and reinforce [4] by forming

${ }^{*}$ Corresponding author: anne@metal.ui.ac.id 
spinel layer $\left(\mathrm{MgAl}_{2} \mathrm{O}_{4}\right)$ [5]. In which case a composite material needs a higher mechanical properties, certain treatments could be applied during the manufacturing such as alloying [6] and heat treatment [1].

In this composite manufacturing, $\mathrm{ADC} 12$, aluminium with $<12 \% \mathrm{Si}$ [7], acts as the matrix while silicon carbide $(\mathrm{SiC})$ was added as the reinforce due to its mechanical properties and load transfer ability [8]. Some modifiers were added to transform the composite's microstructure. The stir casting manufacturing of the composite tends to form dendritic microstructure which results in lowering some mechanical properties [9]. Titanium boron in the form of Al-5Ti-1B were added to suppress dendritic grain growth and producing finer and equiaxed grain. The existence of boron from Al-5Ti-1B also acts as intermetallic stabilizer by the forming of the boride layer [10]. Strontium modifier (Al$15 \mathrm{Sr}$ ) were also added to transform the coarse eutectic silicone into more fibrous and dispersed form [11].

To obtain higher mechanical properties, T6 heat treatment was applied to as-cast composite. This treatment is conducted to gain higher mechanical properties, such as hardness value with a higher nominal than $56 \mathrm{HRB}$, the hardness value of as-cast aluminium composite [12]. This goal of enhancement also targeted to be achieved on other mechanical properties. T6 heat treatment was initiated by solution treatment to solute the existing second phase, resulting the homogenised solid solution. Quenching undergo right after the solution treatment, followed by the artificial aging. Artificial aging involves two process, heating of the material to certain temperature to give the trapped atoms energy which results intermetallic compound and cooling process of the material in the natural room condition [13].

In this work, various artificial aging temperature: $150{ }^{\circ} \mathrm{C} ; 170{ }^{\circ} \mathrm{C} ; 190{ }^{\circ} \mathrm{C} ; 210^{\circ} \mathrm{C}$; and $230^{\circ} \mathrm{C}$ were applied to the composite to examine the effects of different aging temperature to the composite's properties.

\section{Experimental}

\subsection{Materials and methods}

\subsubsection{Materials}

Prior to experiment, composite mass balance calculation was conducted to prepare the materials needed. $547 \mathrm{~g}$ of ADC12 (Si $10.5 \%$; Fe $0.8 \%$; Cu $2.33 \%$; $\mathrm{Mn} 0.22 \%$; $\mathrm{Mg} 0.22 \%$; Zn $0.64 \%$ and $\mathrm{Cr} 0.04 \%$ ) as matrix, $3 \mathrm{Vf} \%$ of $\mathrm{SiC}$ as reinforce, $5 \mathrm{wt} \% \mathrm{Mg}$ as wetting agent, $0.15 \mathrm{wt} \%$ of $\mathrm{TiB}$, and $0.03 \mathrm{wt} \%$ of $\mathrm{Sr}$ were prepared.

\subsubsection{Making of TiB and Sr modified ADC12/SiC composite}

The composite was fabricated using stir casting method. ADC12 were heated in $800{ }^{\circ} \mathrm{C}$ until molten state were obtained. Prior to molten pouring, $\mathrm{SiC}$ were also heated in $900{ }^{\circ} \mathrm{C}$ for $1 \mathrm{~h}$ as pre-treatment. After pre-treatment, $\mathrm{SiC}$ were added to the ADC12 melt, followed by stirring. Addition of $\mathrm{Mg}$ ingot, $\mathrm{TiB}$, and $\mathrm{Sr}$ were conducted right after that, followed by another stirring. Argon degassing were conducted for $2 \mathrm{~min}$ before pouring to the casting die. Casting die was also prepared before pouring by applying zirconia coating and preheating the die in $350{ }^{\circ} \mathrm{C}$ for 2 min to 3 min to minimalize thermal shock.

As cast products then undergo the T6 heat treatment process, starting with the solution treatment for $1 \mathrm{~h}$ in $490{ }^{\circ} \mathrm{C}$ then followed by water quenching in room temperature. 
Artificial aging for $6 \mathrm{~h}$ with temperature variations: $150{ }^{\circ} \mathrm{C} ; 170{ }^{\circ} \mathrm{C} ; 190{ }^{\circ} \mathrm{C} ; 210^{\circ} \mathrm{C}$; and $230{ }^{\circ} \mathrm{C}$, followed by natural aging in room temperature marks the end of the composite samples' fabrication.

\subsection{Characterization}

All post heat treated products were prepared as sample specimens for mechanical testing (tensile strength, hardness, wear rate) and microstructural analysis. Microstructure analysis were conducted using optical microscope $(\mathrm{OM})$, after samples were grinded, polished, and etched using hydrofluoric acid (HF) with $0.5 \%$ concentration for $8 \mathrm{~s}$ to $10 \mathrm{~s}$.

The conducted mechanical tests were: tensile testing using Ogoshi universal testing machine with ASTM E8 standard; Rockwell B hardness testing with ASTM E18 standard; charpy impact testing with ASTM E23 standard; and wear rate testing with ASTM G99 standard. The density of each samples was also measured using Archimedes Theory. All mechanical tests were conducted on room temperature.

\section{Results and discussion}

\subsection{Microstructural analysis of TiB and Sr modified ADC12/SiC composite}
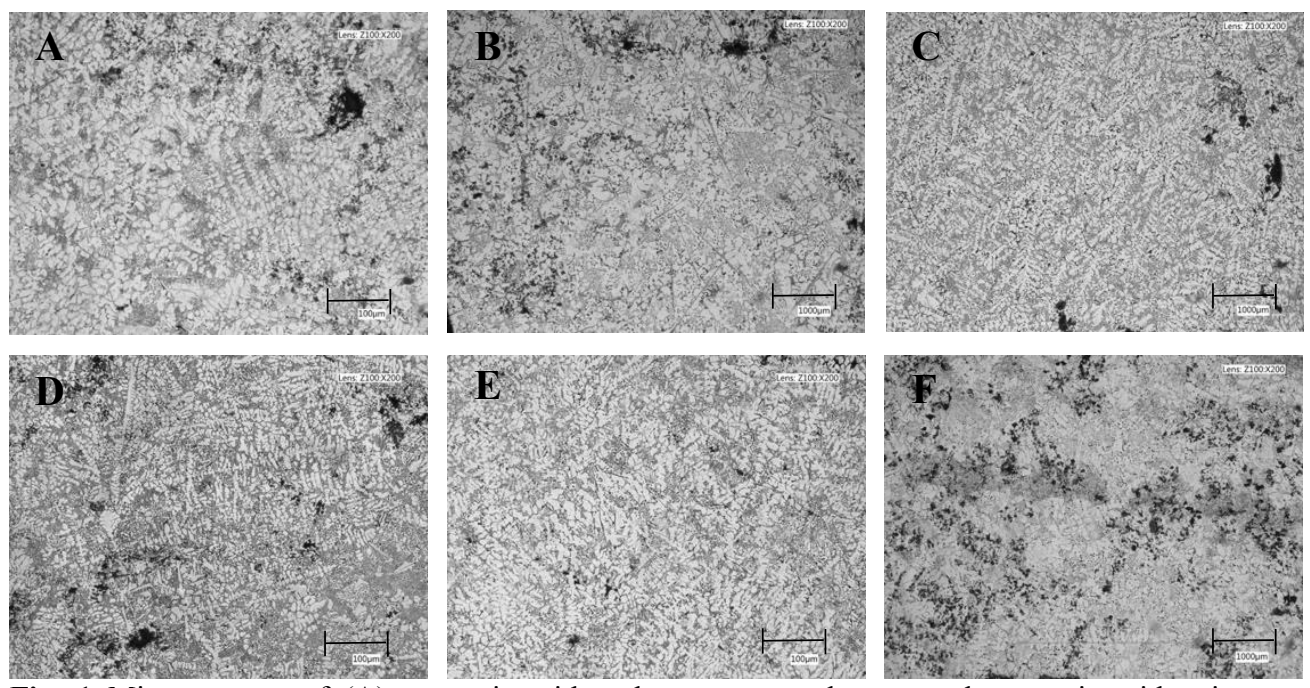

Fig. 1. Microstructure of (A) composite without heat treatment, heat treated composite with aging temperature (B) $150^{\circ} \mathrm{C}$, (C) $170{ }^{\circ} \mathrm{C}$, (D) $190^{\circ} \mathrm{C}$, (E) $210^{\circ} \mathrm{C}$, and (F) $230{ }^{\circ} \mathrm{C}$, with $200 \times$ magnification

The microstructure comparison of $\mathrm{ADC} 12$ and all composite with or without $\mathrm{T} 6$ temperature variations are shown in Figure 1. What distinguish ADC12 microstructure from the composite is the existence needle-like structures which tend to gather stress concentration in the material. Significant microstructure transformation can be seen within all composite with T6 temperature variation samples. The needle-like structures transformed to more spherical structure in composite, with different growth in each sample. The growth of columnar grains in $150^{\circ} \mathrm{C}$ and $170^{\circ} \mathrm{C}$ samples can be seen, in which higher aging temperature produces more spherical and finer columnar grains. The decreasing of secondary dendritic arm spacing (SDAS) can also be seen as the aging temperature rises. Finer, spherical grains with lower dendritic arm spacing reduces stress concentration in 
material structure, which will affect the material's toughness. The increasing of aging temperature shows parallel relation in grain growth, in which higher aging temperature will trigger bigger columnar grains and the dendrites tend to be more spherical. Sample with $230{ }^{\circ} \mathrm{C}$ has bigger columnar grain size than the other samples. However, the dendrite arm spacing shows different trend shown in Figure 2, in which it shows lowering of dendritic arm spacing from $150{ }^{\circ} \mathrm{C}$ to $170{ }^{\circ} \mathrm{C}$ samples, but then increases respectively in $190{ }^{\circ} \mathrm{C}$, $210^{\circ} \mathrm{C}$, and $230^{\circ} \mathrm{C}$ samples.

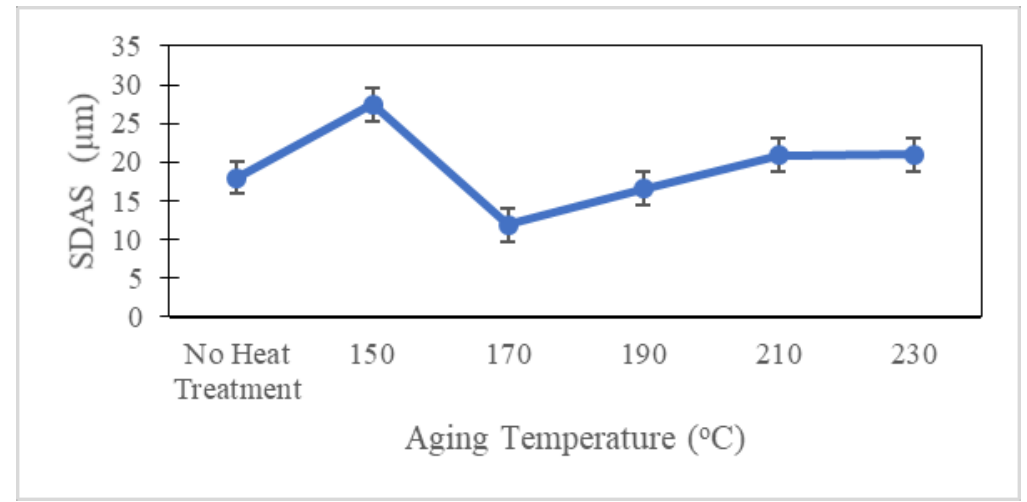

Fig. 2. Effect of aging temperature to composite dendritic arm spacing

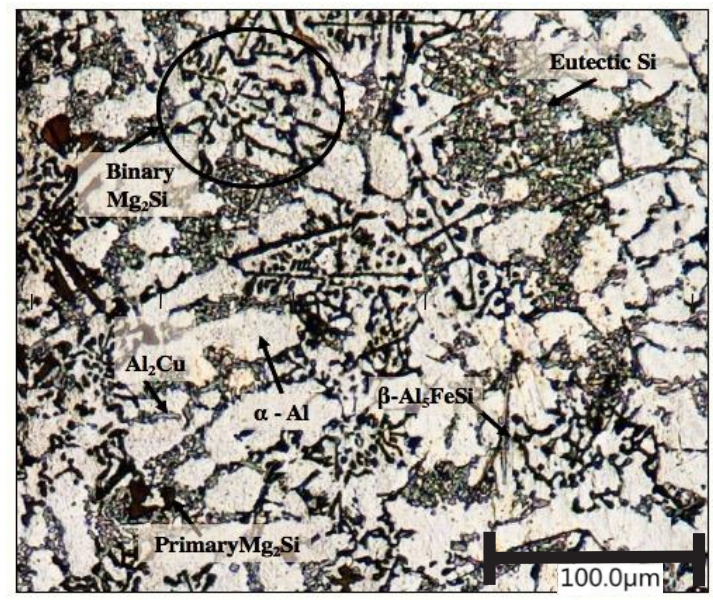

Fig. 3. Phases in $\mathrm{T} 6$ heat treated $\mathrm{TiB}$ and $\mathrm{Sr}$ Modified ADC12/SiC Composite

From the Figure 1 and Figure 3, the existing phase in the materials can also be seen. As labelled in Figure 3, the existing phases are primary $\mathrm{Mg}_{2} \mathrm{Si}$, Chinese script form of binary $\mathrm{Mg}_{2} \mathrm{Si}$, eutectic silicone which clusters in some areas, $\mathrm{Al}_{2} \mathrm{Cu}$ in the light grey form, needlelike $\beta-\mathrm{Al}_{5} \mathrm{FeSi}$ and $\alpha$-Aluminium. The existing phase are correlated with the chemical composition of the composite, shown in Table 1 and the $\mathrm{x}$-ray diffraction analysis shown in Figure 4.

Compared to $\mathrm{ADC12}$, the composite shows higher amount of magnesium which were added as wetting agent, resulting in $\mathrm{Mg}_{2} \mathrm{Si}$ formation with the reaction: $\mathrm{L} \rightarrow \mathrm{Al}+\mathrm{Si}+$ $\mathrm{Mg}_{2} \mathrm{Si}$. The existing magnesium tends to form $\mathrm{Mg}_{2} \mathrm{Si}$ in both primary and binary form which results in the enhancement of mechanical properties. Ti amount in the composite is also related to the existence of $\mathrm{Al}_{3} \mathrm{Ti}$ and $\mathrm{TiB}_{2}$ intermetallic compound, from the $\mathrm{TiB}$ 
addition, which act as nucleating compounds in the composite [14]. The Fe content in the composite is suspected to come from the fabrication, resulting the existence of $\mathrm{Al}_{5} \mathrm{FeSi}$, $\mathrm{Al}_{8} \mathrm{FeMg}{ }_{3} \mathrm{Si}[15]$ and $\beta-\mathrm{Al}_{5} \mathrm{FeSi}[16]$. Based on the XRD analysis in Figure 4, the existence of aluminium and magnesium in the composite also form $\mathrm{MgAl}_{2} \mathrm{O}_{4}$ or spinel that plays role in enhancing material properties.

Table 1. Chemical composition of ADC 12 and composite

\begin{tabular}{|l|l|l|l|l|l|l|l|l|}
\hline & $\mathrm{Al}$ & $\mathrm{Si}$ & $\mathrm{Fe}$ & $\mathrm{Cu}$ & $\mathrm{Mg}$ & $\mathrm{Cr}$ & $\mathrm{Ti}$ & $\mathrm{Sr}$ \\
\hline ADC12 & 84.8 & 10.5 & 0.86 & 2.33 & 0.22 & 0.038 & 0.046 & $<0.0001$ \\
\hline Composite & 77.6 & 12.7 & 1.74 & 1.84 & 4.97 & 0.182 & 0.126 & 0.00643 \\
\hline
\end{tabular}

From Figure 3, a needle-like form is predicted as $\beta-\mathrm{Al}_{5} \mathrm{FeSi}$ phase, while another phase which may be formed near the phase is intermetallic $\mathrm{Al}_{2} \mathrm{Cu}$. This is in accordance with the solidification reaction of the Al-Si-Cu-Fe quartener [17] which occurs at a temperature of $525{ }^{\circ} \mathrm{C}$, with the reaction: $\mathrm{L} \rightarrow \mathrm{Al}+\mathrm{Si}+\mathrm{Al}_{2} \mathrm{Cu}+\mathrm{Al}_{5} \mathrm{FeSi}$. However, with the addition of $\mathrm{Mg}$, the formation of $\pi-\mathrm{Al}_{8} \mathrm{Mg}_{3} \mathrm{FeSi}_{6}$ is possible from the $\beta-\mathrm{Al}_{5} \mathrm{FeSi}$. This will produce better mechanical properties than needle-like form, as it will increase the ductility.

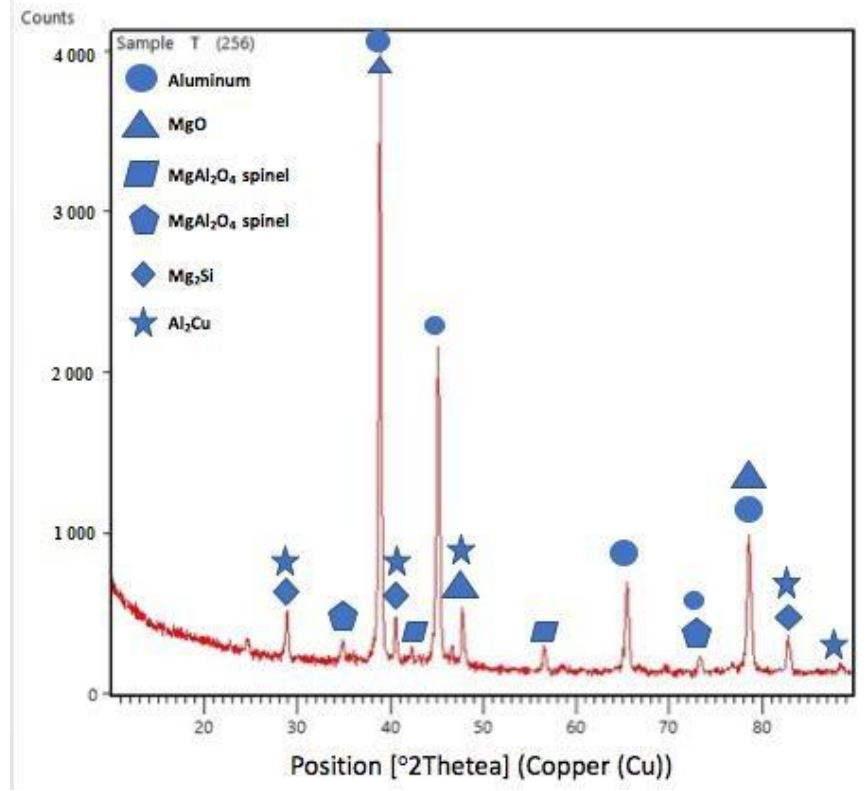

Fig. 4. XRD pattern of $\mathrm{TiB}$ and $\mathrm{Sr}$ modified $\mathrm{ADC} 12 / \mathrm{SiC}$ composite.

\subsection{Mechanical properties}

\subsubsection{Composite density}

All of the composite samples were fabricated with the same method and composition. Based on the measurement, the composite density value is $2.63 \mathrm{gr} \mathrm{cm}^{-3}$. This is value is lower than $\mathrm{ADC} 12\left(2.76 \mathrm{gr} \mathrm{cm}^{-3}\right)$ as the effect of the lower-density alloying elements such as magnesium $\left(1.74 \mathrm{gr} \mathrm{cm}^{-3}\right)$ and $\mathrm{Al}-15 \mathrm{Sr}$ alloys $\left(2.69 \mathrm{gr} \mathrm{cm}^{-3}\right)$ to the composite. This lowering of density value is also associated with the presence of $\mathrm{Mg}_{2} \mathrm{Si}$ phase which has low density $\left(1.9 \mathrm{gr} \mathrm{cm}^{-3}\right)$ [18]. 

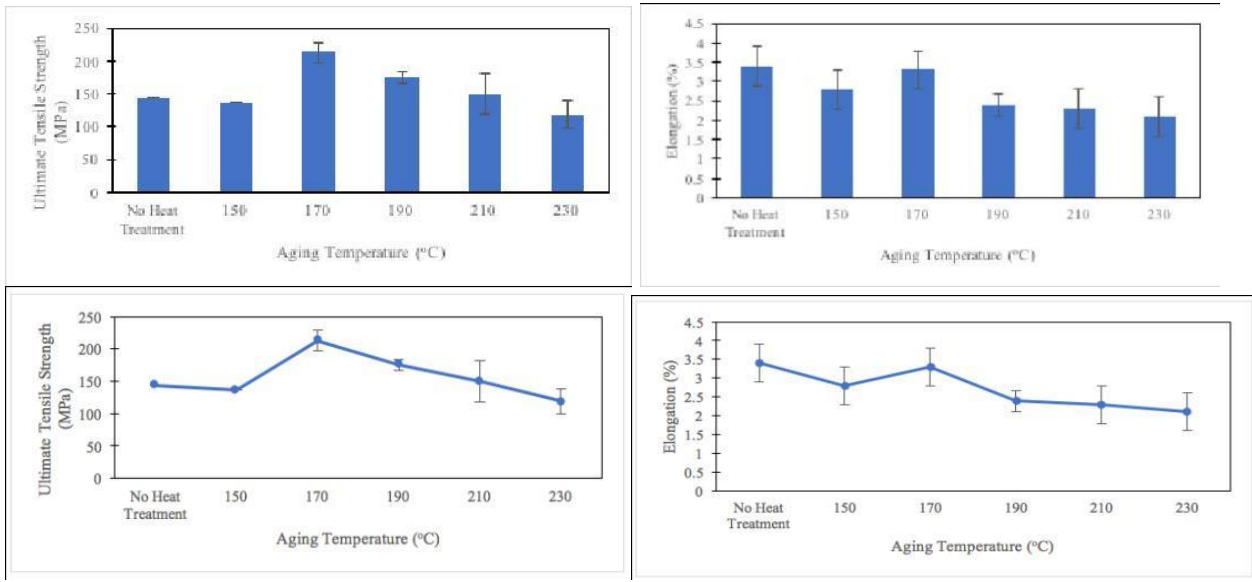

Fig. 6. Ultimate tensile strength (left) and elongation (right) of composite.

\subsubsection{Tensile and elongation}

Ultimate tensile strength (UTS) of composite with variation of T6 aging temperature are shown in Figure 6. Composite with $170{ }^{\circ} \mathrm{C}$ aging temperature achieve the highest UTS value. This value is higher from the composite with lower aging temperature, $150{ }^{\circ} \mathrm{C}$, also the other composite with higher aging temperature. This higher value is the impact of the peak age, which is obtained at the $170{ }^{\circ} \mathrm{C}$ temperature. Higher temperature above the optimum temperature triggers the excessive microstructural growth as the result of over aging phenomenon. Over aging made phases like $\mathrm{Mg}_{2} \mathrm{Si}, \mathrm{Al}_{2} \mathrm{Cu}$, and $\mathrm{Cu}_{2} \mathrm{Mg}_{8} \mathrm{Si}_{6} \mathrm{Al}_{5}$ to be incoherent while it actually already reached its semi-coherent state before (while peak age). This results in decreasing of some mechanical properties, including tensile strength. From Figure 6 it can also be seen that higher tensile strength is also parallel with the higher $\%$ elongation. The higher UTS value and elongation are the result of the material's homogenization, which was obtained from the heat treatment process. Modifiers also play role in microstructural evolution, which results in finer and spherical columnar grains.

\subsubsection{Hardness and wear rate}

The hardness value of composite increases as the aging temperature escalates, but then decreases after certain temperature when over aging phenomenon occurs. This trend is quite similar with the tensile strength results, in which both UTS and highest hardness value are achieved with $170{ }^{\circ} \mathrm{C}$ aging temperature. However, sample with $190{ }^{\circ} \mathrm{C}, 210{ }^{\circ} \mathrm{C}$ and $230{ }^{\circ} \mathrm{C}$ aging temperature only shows minor significance in hardness value reduction.

Figure 7 wear rate data also shows that material with higher hardness value will tend to have lower wear rate, because the hardness properties of a material is directly related on its ability to prevent material loss when it is exposed to abrasion, erosion, or other wear mechanisms. 

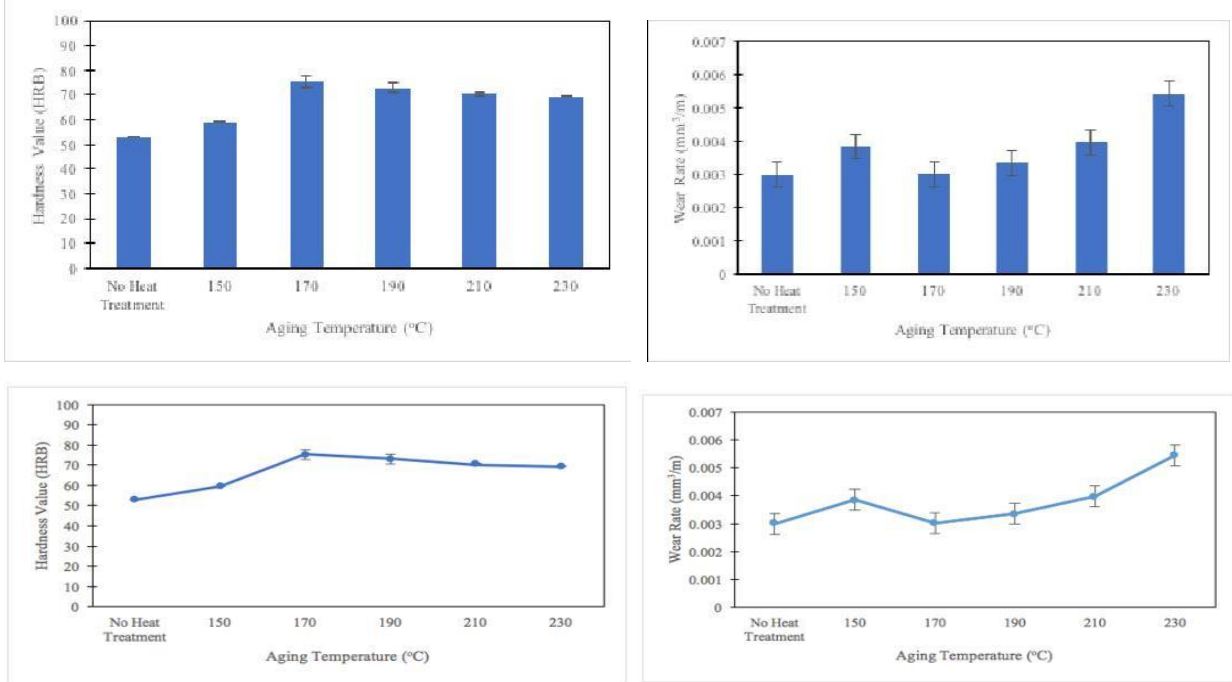

Fig. 7. Hardness value (left) and wear rate (right) of composite.

\section{Conclusion}

ADC 12/SiC composite with $\mathrm{TiB}$ and $\mathrm{Sr}$ that undergo T6 heat treatment can be considered as a better material choice for various utilization, such as for automotive industry usage that demands wear resistant, hardness, durability, high tensile strength, and other requirements. This is because the higher mechanical properties are obtained with the optimum aging temperature at $170^{\circ} \mathrm{C}$. It reaches $213 \mathrm{MPa}$ in ultimate tensile strength (UTS) and $75 \mathrm{HRB}$ in hardness value. The T6 heat treatment triggers not only grain and phase transformation, but also material structure homogenization, which also results in enhanced mechanical properties such as higher elongation percentage with higher tensile strength. The decreasing material properties with higher aging temperature $\left(190{ }^{\circ} \mathrm{C}\right.$ and above $)$ in this work is occurred due to over aging phenomenon.

This enhancement is also supported by the addition of TiB and $\mathrm{Sr}$ modifier, also magnesium as the wetting agent. Magnesium addition enable the formation of intermetallic phases such as $\mathrm{Mg}_{2} \mathrm{Si}$ and spinel $\left(\mathrm{MgAl}_{2} \mathrm{O}_{4}\right)$, which also affected the material's mechanical properties. The existence of iron also holds roles in phase formation, which resulted $\beta$-Fe and $\pi$-Fe phase.

This research is supported by University of Indonesia through its Research Grant Program (HIBAH PITTA tahun 2018, Nomor: 2378 UN2.R3.1/HKP.05.00/2018).

\section{References}

1. B. T. Sofyan, Pengantar Material Teknik. [Introduction to Engineering Materials] Jakarta: Salemba Teknika, 2010. [in Bahasa Indonesia]. http://library.um.ac.id/freecontents/index.php/buku/detail/pengantar-material-teknik-bondan-t-sofyan-40488.html

2. ASM. ASM handbook Volume 4. Ohio: ASM International (1991). https://www.bookdepository.com/ASM-Handbook-Vol-4-ASMInternational/9780871703798 
3. M.K. Surappa. Sadhana. 28,1-2:319-334(2003).

https://link.springer.com/article/10.1007/BF02717141

4. G.N.A. Sahari, A. Zulfia, E.S. Siradj, Makara Sains, 13,1:39-44(2009). http://repository.ui.ac.id/contents/koleksi/2/fc74a5bdddbe7155a4beac32712d8a72c9cf 0cc8.pdf

5. A. Sangghaleh, M. Halali. Applied Surface Science, 255,19:8202-8206(2009). https://www.sciencedirect.com/science/article/pii/S0169433209006394?via\%3Dihub

6. S. Farahany, A. Ourdjini, M.H. Idrsi, S.G. Shabestari, Thermochim. Acta, 559:5968(2013). https://www.sciencedirect.com/science/article/abs/pii/S0040603113001019

7. R. Cobden, A. Banbury. Aluminium: Physical properties, characteristics and alloys. Brussels: Talat, European Aluminium Association (1994). p. 60. https://www.slideshare.net/corematerials/talat-lecture-1501-properties-characteristicsand-alloys-of-aluminium

8. ASM. ASM handbook Vo. 21. Ohio: ASM International (2001). https://www.asminternational.org/documents/10192/22533690/06781G ToC_2018+\% 281\%29.pdf/813f8d0f-dcc3-faad-e21c-fd7db7507daf

9. K.G. Basavakumar, P.G. Mukunda, M. Chakraborty, Mater. Charact., 59,3:283289(2008). https://www.sciencedirect.com/science/article/pii/S1044580307000319

10. K.T. Kashyap, T. Chandrashekar, Bulletin of Materials Science, 24,4:345-353(2001). https://link.springer.com/article/10.1007/BF02708630

11. J. Asensio-Lozano, B. Suarez-Peña, Scr. Mater., 54,5:943-947(2006). https://www.sciencedirect.com/science/article/pii/S1359646205007104

12. A. Akkus, M. Yegin, Int. J. Appl. Sci. Technol., 4,7:76-84(2014). http://www.ijastnet.com/journals/Vol 4 No 7 December_2014/10.pdf

13. E. Sjölander, S. Seifeddine, Mater. Des., 31,SUPPL. 1:S44-S49(2010). https://www.sciencedirect.com/science/article/pii/S0261306909005895

14. M. StJohn, D. Easton, Metall. Mater. Trans. A, 30,6:1613-1623(1999). https://link.springer.com/article/10.1007/s11661-999-0098-5

15. J.E. Gruzleski, B.M. Closset, The treatment of liquid aluminum-silicon alloys. Illinois: American Foundrymen's Society, Inc, (1990). https://www.amazon.com/TreatmentLiquid-Aluminum-Silicon-Alloys-Gruzleski/dp/0874331218

16. S. Ji, W. Yang, F. Gao, D. Watson, Z. Fan, Mater. Sci. Eng. A, 564:130-139(2013). https://www.sciencedirect.com/science/article/pii/S0921509312016474

17. L.F. Mondolfo, Aluminum Alloys: Structure and Properties. Boston: Butterworths (1976).

https://books.google.co.id/books/about/Aluminum_alloys.html?id=Uu5UAAAAMAAJ \&redir_esc $=\mathrm{y}$

18. Z.L. Huang, K. Wang, Z.M. Zhang, B. Li, H.S. Xue, D.Z. Yang. Trans. Nonferrous Met. Soc. China (English Ed.), 25,10:3197-3203(2015).

https://www.sciencedirect.com/science/article/abs/pii/S1003632615639565 